\title{
Quality Education and Skills of Indonesian Labor, Towards Equality Wages in Foreign Countries
}

\author{
Febriani \\ Faculty of Economics, Universitas Tamansiswa Padang \\ Jl. Tamansiswa 9 Padang 24138 Indonesia, Phone +62-751-40020 \\ E-mail address: febrianiopet@yahoo.co.id
}

\begin{abstract}
This study examines the influence of the quality of education and skills of prospective Indonesia Labor from West Sumatra on income. Wage income is expected equivalent to the level of wage labor which comes from other countries. Therefore, in order to obtain equal wage, prospective Indonesian labors sent abroad should be a good level of education, skill trained so that labor productivity increased. The method used in this study is Test Crosstab, and, Chi Square test to see the effect between the two variables used. It is shown that Indonesian labors do not able to compete in terms of quality of education and skills, compared to foreign labors, so that the income received by the Indonesian labor is lower. In addition, professional job that has been chosen by the Indonesian labor is the operator, profession which does not necessarily require a high level of educational and skills qualifications.
\end{abstract}

Keywords: indonesia worker, education, skill, remittance

JEL Classification Codes: E24, J2, J6,

\section{Kualitas Pendidikan dan Keterampilan Tenaga Kerja Indonesia, Menuju Kesetaraan Upah di Luar Negeri}

\begin{abstract}
Abstrak
Penelitian ini bertujuan melihat pengaruh kualitas pendidikan dan keterampilan calon tenaga kerja Indonesia dari Sumatera Barat terhadap pendapatan. Pendapatan upah ini diharapkan setara dengan upah tenaga kerja yang berasal dari negara lain. Oleh karenanya agar ada kesetaraan upah, calon tenaga kerja Indonesia yang dikirim ke luar negeri benar-benar yang memiliki tingkat pendidikan yang baik, keterampilan yang terlatih sehingga produktivitas kerja meningkat. Metode yang digunakani dalam penelitian ini adalah Uji Crosstab dan uji Chi Square untuk melihat pengaruh antara dua variabel yang digunakan. Hasil penelitian terlihat bahwa tenaga kerja Indonesia tidak mampu bersaing dalam hal kualitas pendidikan dan keterampilan dengan tenaga kerja asing di luar negeri, sehingga pendapatan yang diterima tenaga kerja Indonesia lebih rendah. Di samping itu, profesi pekerjaan yang banyak dipilih oleh tenaga kerja Indonesia adalah operator, profesi yang tidak terlalu tinggi kualifikasi tingkat pendidikan dan keterampilannya.
\end{abstract}

Kata kunci: tenaga kerja Indonesia, pendidikan, keterampilan, pengiriman uang Kode Klasifikasi JEL: E24, J2, J6 


\section{Pendahuluan}

Hampir setiap hari kita melihat tayangan televisi tentang permasalahan TKI di luar negeri. Mulai dari pemulangan ke daerah asal, penyiksaan dan penyanderaan TKI. Hal ini terjadi karena kurangnya perlindungan dan kualitas dari TKI yang dikirim sebagai akibat dari rendahnya tingkat pendidikan dan keterampilan yang dimiliki. Permasalahan tenaga kerja selalu menjadi agenda utama dalam setiap pergantian pemerintah dan menjadi agenda tetap dalam mengatasi pengangguran setiap tahunnya (Elfindri \& Rimilton Riduan, 2008). Salah satu solusi untuk mengatasi pengangguran ini adalah dengan mengirimkan mereka bekerja keluar negeri (Bachtiar, 2004; Darwis, 2004; Wisnu Adi, 2007; Waridin, 2002). Namun persoalan yang muncul sekarang ini adalah sampai sejauh mana kualitas dari TKI yang dikirim dan apakah pendidikan dan keterampilan yang dimiliki sudah sesuai dengan kebutuhan negara pengguna atau user?

Akan tetapi jawaban sesungguhnya yang belum terungkap saat ini adalah bagaimana kemampuan kompetensi keahlian yang dimiliki oleh TKI tersebut, apakah pelatihan keterampilan yang telah dilakukan secara berjenjang, terkait dan berkelanjutan? Di samping itu apa upaya yang telah dilakukan oleh pihak terkait (Disnakertrans dan PJTKI)? Untuk menjawab pertanyaan di atas sudah banyak tersedia berbagai jawabannya. Karena para peneliti sudah banyak menghasilkan berbagai jawaban tentang kualitas TKI. Banyak juga saran yang perlu dijalankan oleh pihak terkait agar yang dirancang betul-betul bisa mengatasi persoalan yang ada. Permasalahan TKI semakin ruwet dan panjang seperti mengurai benang kusut.

Berbagai persoalan TKI diatas, kita tidak mencari siapa yang salah dan paling bertanggungjawab. Bagaimanapun kita semua harus bertanggungjawab dalam mengurangi permasalahan TKI diluar negeri. Tulisan ini mencoba untuk melihat "Kualitas Pendidikan dan Keterampilan TKI Menuju Kesetaraan Upah di Luar Negeri: Sebuah Rekonstruksi". Pengiriman TKI keluar negeri dimasa yang akan datang perlu diperbaiki dengan meningkatkan kualitas pendidikan dan keterampilan mereka. Di samping itu para TKI harus mendapatkan perlindungan dan pendapatan yang diterima sama dengan tenaga kerja dari negara lain sehingga bangsa Indonesia dihargai di mata dunia Internasional.

Bagi tenaga kerja, dimanapun bekerja baik di luar negeri maupun di dalam negeri pendidikan dan keterampilan sangat penting, karena akan menentukan tingkat produktivitas yang dihasilkan. Pada tahun 2008 Sumatera Barat telah mengirimkan sebanyak 1.852 Tenaga Kerja Indonesia (TKI) asal berbagai kabupaten/kota ke luar negeri khususnya ke Malaysia (Febriani, 2008). Pemerintah daerah Sumatera Barat telah mengirimkan TKI secara resmi dengan sektor pekerjaan yang dimasuki sebagai operator dan kontruksi bangunan.

Pentingnya Pendidikan dan Keterampilan bagi Tenaga Kerja. Tenaga kerja yang berkualitas adalah tenaga kerja terdidik dengan tingkat keahlian dan keterampilan yang mampu berkompetisi dengan tenaga kerja dari manapun. Tenaga kerja terdidik dapat diklasifikasikan menjadi tenaga kerja mandiri dan tenaga kerja professional (Latief, 1995:103). Tenaga kerja mandiri adalah orang berusia 2535 tahun, yang mempunyai idealisme dan integritas kepribadian yang tinggi tanpa tergantung pada orang lain dan mampu menghasilkan karya nyata dalam bentuk usaha yang produktif dan bermanfaat bagi masyarakat luas. Sedangkan kemampuan yang dimiliki oleh seseorang sesuai dengan bakat dan minat yang diwujudkan dalam suatu usaha nyata baik berupa barang maupun jasa yang dapat memberikan penghasilan bagi diri sendiri dan memberikan kepuasan pada orang lain adalah merupakan tenaga kerja yang professional.

Pendidikan pada dasarnya lebih menekankan pada pembentukan kualitas dasar tenaga kerja serta pengembangan kompetisi, sedangkan keterampilan pengembangan ditempat kerja merupakan upaya penempatan aplikasi kompetensi untuk menghasilkan produktivitas yang tinggi. Untuk mendapatkan semuanya itu perlu kerjasama antara lembaga pendidikan, lembaga pelatihan dan swasta dalam peningkatan kualitas tenaga kerja yang merupakan tanggungjawab bersama antara pemerintah, 
masyarakat dan badan usaha swasta lainnya. Kerena itu, pendidikan dan pelatihan yang diprioritaskan harus relevan dengan kebutuhan pasar kerja. Sehingga daya serap lulusan akan lebih besar pada pasar kerja dan dunia usaha, sekaligus mempunyai dampak produktivitas yang berakibatkan peningkatan pendapatan pekerja. Dengan peningkatan pendapatan tenaga kerja maka keinginan untuk menciptakan lapangan pekerjaan semakin terbuka sehingga ketidaksepadanan (mismatch) antara tenaga kerja dan lapangan kerja tidak perlu terjadi.

Dengan adanya reformasi, diharapkan pendidikan dan pelatihan lebih respontif terhadap kebutuhan pasar kerja dan dunia usaha, sehingga relevansi kualitas dan efisiensi penyelenggaraan pendidikan dan pelatihan dapat lebih ditingkatkan terutama:

a. Pendidikan dan pelatihan yang mendukung program penempatan pencari kerja dan penaggulangan pengangguran.

b. Pendidikan dan pelatihan untuk mendukung program peningkatan produktivitas dan kesejahteraan pekerja.

c. Pendidikan dan pelatihan yang mendukung program ekspor jasa tenaga kerja.

Pendidikan dan Keterampilan Merupakan Investasi. Pendidikan yang diperoleh disekolah dan pelatihan keterampilan adalah satu-satunya bentuk dari investasi modal yang dapat mempengaruhi penghasilan. Penghasilan akan meningkat setelah pendidikan selesai (lulus dari sekolah). Pendidikan formal biasanya selesai pada umur 25 (dua puluh lima) tahun, namun penghasilan mungkin tetap konstan sepanjang kelompok umur tersebut, jika ingin menaikan produktivitas lulusan perguruan tinggi melalui investasi dalam pelatihan di tempat kerja, meskipun profit tersebut meningkat melalui masa kerja. Hal ini dapat dilihat pada Grafik 1.

Pada Grafik 1 memperlihatkan rata-rata penghasilan dengan lulusan sekolah, dimana pada tingkat lulusan sekolah/ pendidikan yang rendah (lulusan SLTA ke bawah) dan sedikit keterampilan atau bahkan sama sekali tidak pernah mengikuti pelatihan keterampilan akan memperoleh penghasilan yang rendah namun mereka menikmati hasil tersebut. Bagi lulusan perguruan tinggi, profit penghasilan yang diterima lebih banyak dari pada lulusan sekolah SLTA ke bawah.

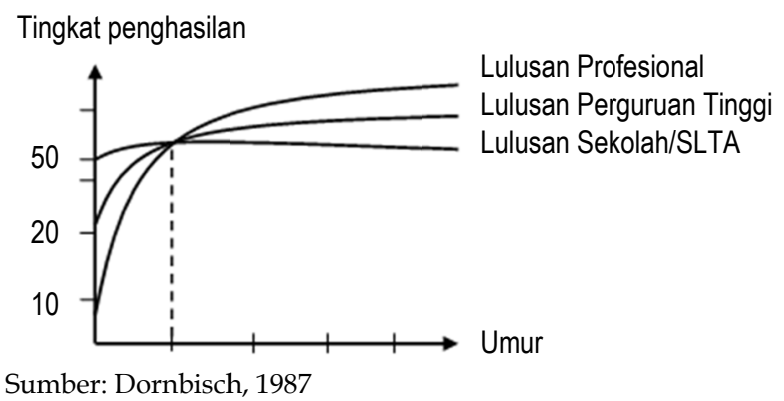

\section{Gambar 1. Rata-Rata Penghasilan dengan Tingkat Pendidikan}

Sedangkan pada tingkat lulusan profesional, yaitu mereka yang memiliki lebih tinggi pendidikan dan memperoleh pelatihan keterampilan yang memadai akan memperoleh profit penghasilan yang lebih besar dibandingkan dengan mereka yang lulus sekolah dan perguruan tinggi tetapi tidak/ sedikit memperoleh pelatihan keterampilan.

\section{Metode Penelitian}

Penelitian ini dilakukan pada dua PJTKI di Kota Padang, adapun PJTKI yang terpilih adalah PT. Andalan Mitra Prestasi (AMP) dan PT. Mitra Muda Raksa Mandiri. Kedua PJTKI tersebut paling banyak mengirimkan calon TKI asal Sumatera Barat keluar negeri. Populasi dari penelitian ini adalah calon TKI yang mendaftar pada dua perusahaan PJTKI yang dipilih dengan jumlah sampel sebanyak 120 orang. Teknik dalam pengambilan sampel menggunakan sampel random sederhana (simple random sampling).

Metode yang diaplikasikan dalam penelitian ini adalah penggunaan Crosstab (Tabel Silang) dan uji Chi Square (kuadrat Chi). Crosstab digunakan untuk melihat pengaruh antara dua variable yang digunakan. Sedangkan uji Chi Square digunakan karena data yang digunakan berupa perhitungan frekuensi dari variable yang digunakan. Hasil perhitungan uji Chi Square dinyatakan dengan nilai $X^{2}$. Nilai $X^{2}$ diperoleh dengan membandingkan antara rata-rata hitung variabel yang diuji (frekuensi observasi) dengan rata-rata frekuensi yang 
diharapkan dengan derajat kebebasan (degree of freedom) $=\mathrm{k}-1$. Rumus Chi Square (Sugiyono, Wibowo, 2004) yang dipergunakan untuk menghitung nilai $X^{2}$ adalah:

$$
X^{2}=\sum \frac{(O-E)^{2}}{E}
$$

dimana: $X^{2}$ adalah Chi Square; O adalah Frekuensi observasi, E adalah Frekuensi harapan

Jika nilai $X^{2}$ sama atau lebih besar dari nilai Chi Square table taraf signifikansi 0,05 maka nilai $X^{2}$ tersebut dinyatakan signifikan, hal itu berarti hipotesis tersebut ditolak. Artinya, terdapat perbedaan yang signifikan antara Chi

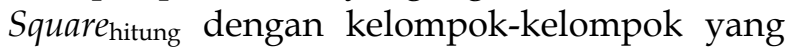
diuji. Sebaliknya jika $X^{2}$ yang diperoleh lebih kecil dari nilai Chi Square table berarti hipotesis tersebut diterima. Dengan artikata, tidak ada perbedaan yang signifikan antara rata-rata hitung tiap kelompok-kelompok yang diuji atau dengan kata lain berdasarkan nilai probabilitas. Jika probabilitas $>0,05$, maka $\mathrm{H}_{0}$ diterima Jika probabilitas $<0,05$, maka $\mathrm{H}_{\mathrm{a}}$ ditolak

\section{Hasil dan Pembahasan}

\section{Karakteristik Responden}

1. Jenis Kelamin. Hasil survey yang dilakukan (Maret-Mei 2009) dengan 120 responden, ditemukan bahwa pengiriman TKI keluar negeri lebih didominasi oleh wanita yaitu 83,3 persen dan laki-laki sekitar 16,7 persen. Dari data ketenagakerjaan tahun 2008 Disnakertrans propinsi Sumatera Barat untuk pengiriman TKI selama lima tahun terakhir (2004-2008) dimana wanita juga lebih dominan. Ini terjadi karena permintaan perusahaan di luar negeri lebih banyak ke pada tenaga kerja wanita karena tingkat kedisiplinan yang tinggi, patuh dan taat terhadap aturan yang ditetapkan oleh perusahaan. Sedangkan laki-lakinya kurang disiplin dalam bekerja dan juga memiliki sikap (attitude) dan pola sikap "Attitude inilah yang perlu diubah, karena tidak dapat ditampik sikap orang Minang Taimpik Nak di Ateh, Takuruang Nak di Lua, yang telah menghambat sikap atau pola tingkah dari laki-laki tersebut," sehingga perusahaan di luar negeri lebih memilih tenaga kerja wanita dari pada laki-laki (Wawancara dengan pimpinan PJTKI. PT.AMP/ 26/3/08).

2. Usia. Ravenstein (1985) dalam "Hukum Migrasinya" menyatakan migran biasanya adalah penduduk golongan muda/usia produktif. Pada usia ini mereka dianggap lebih mampu mengembangkan dan menyesuaikan diri dibandingkan dengan penduduk golongan tua (Nasution, 2001). Beranjak dari pandangan tersebut hasil survei menemukan bahwa usia TKI asal Sumatera Barat tergolongan usia muda/usia produktif yaitu antara usia 20-24 tahun (65 persen), sedangkan usia $<20$ tahun (11 persen) lebih sedikit karena pada usia tersebut mereka masih sekolah dan biasanya masih bergantung pada orang tua, sedangkan usia $>24$ tahun lebih berkurang ( 24 persen) karena pada usia ini sektor pekerjaan yang dimasuki tidak cocok lagi dengan usia tenaga kerja (sebagai operator) dan mereka lebih memilih untuk berumah tangga dengan bekerja di daerah asal.

3. Status Perkawinan. Sebagian besar tenaga kerja asal Sumatera Barat yang bekerja keluar negeri belum menikah yaitu sekitar 97,5 persen dan kalaupun sudah menikah itu jumlahnya sangat kecil (2,5 persen). Hal ini disebabkan karena mereka setelah tamat sekolah (SLTA) memperoleh informasi untuk bekerja keluar negeri dari tetangga atau teman yang bekerja di luar negeri gunanya untuk mengumpulkan modal kala menikah nantinya. Sedangkan bagi mereka yang telah menikah keinginan untuk bekerja keluar negeri semakin berkurang karena beban psykis meninggalkan keluarga lebih besar dari pada keinginan bekerja keluar negeri.

4. Jumlah Anggota Keluarga. Berkenaan dengan jumlah anggota keluarga sebagaimana yang dikatakan Nasution (1997) kepergian migrant keluar negeri umumhya disebabakan karena jumlah tanggungan keluarga relative besar apalagi banyak diantaranya tidak bekerja. Hasil penelitian menemukan jumlah anggota keluarga calon TKI rata-rata antara 5-8 orang. Responden sejumlah seratus dua puluh orang di antaranya 70 persen memiliki jumlah anggota keluarga 5-8 orang satu keluarga dan bahkan ada di antara responden tersebut memiliki jumlah anggota keluarga sampai 10 atau 11 orang dalam satu keluarga. Dengan 
latar belakang jumlah anggota keluarga yang banyak inilah maka calon tenaga kerja lebih memilih bekerja keluar negeri untuk membatu ekonomi keluarga yang pada umumnya orang tua mereka bekerja sebagai petani di daerah asal.

5. Latar Belakang Ekonomi Keluarga. Sudah lumrah bahwa latar belakang kehidupan ekonomi keluarga TKI yang sulit, banyak dijadikan alasan untuk mengambil keputusan bekerja keluar negeri. Hasil wawancara dan survey yang dilakukan menyatakan bahwa menjadi TKI ke luar negeri disebabkan latar belakang kehidupan ekonomi yang kurang menguntungkan, dan kalaupun mereka bekerja didaerah asal akan memperoleh pendapatan yang lebih kecil bahkan tidak mencukupi untuk memenuhi kebutuhan hidup sehari-hari. Kebanyakan orang tua responden memiliki pekerjaan sebagai petani $(50,8$ persen) atau berdagang kecilkecilan (16,7 persen) dan kalaupun ada yang pegawai negeri sipil dengan golongan rendah itupun jumlahnya lebih sedikit yaitu sekitar 2,5 persen. Harapan bekerja keluar negeri dengan pendapatan yang diterima lebih besar dibandingkan dengan bekerja di dalam negeri sehingga akan membawa ekonomi keluarga yang lebih baik.

6. Negara Tujuan Bekerja. Selanjutnya bukan rahasia lagi, bahwa tenaga kerja Indonesia khususnya Sumatera Barat lebih banyak memilih negara tujuan bekerja adalah Malaysia dibandingkan dengan negara lain. Dari hasil survey yang dilakukan pada PJTKI di Kota Padang, menyatakan bahwa seluruh calon tenaga kerja memilih Malaysia sebagai negara tujuan bekerja karena bahasa yang digunakan mudah dimengerti, budaya serta agama yang sama. Selain dari bahasa yang digunakan mudah dimengerti, juga faktor lain yang menyebabkan mereka memilih Malaysia adalah karena banyaknya teman-teman yang bekerja di Malaysia. Sehingga informasi tentang kondisi dan situasi bekerja di Malaysia yang lebih banyak mereka peroleh sedangkan informasi tentang negara lain lebih sedikit atau bahkan tidak mereka dapatkan.

Memahami Pentingnya Pendididkan dan Keterampilan Sebagai Kunci Sukses Bagi Tenaga Kerja Indonesia
Bagi para tenaga kerja, baik yang bekerja di dalam negeri maupun di luar negeri yang penting adalah upah yang diterima dan tingkat keberhasilan dalam bekerja sebagai salah satu tujuan bekerja, dengan memperhatikan dan memahami tingkat pendidikan dan kualitas keterampilan sebagai salah satu alat pencapaian tujuan. Dalam tataran prakteknya banyak para tenaga kerja dalam bekerja melakukan pilihanpilihan efektif dari sebuah pemahaman yang akan membantu pencapaian tujuan yang diharapkan baik bagi tenaga kerja maupun pihak pengguna. Tujuan-tujuan tersebut bisa dijadikan salah satu pintu untuk mencapai keberhasilan dan kesuksesan.

Langkah-langkah berikutnya adalah dengan cara bagaimana mewujudkan tujuan tenaga kerja dengan pihak pengguna agar salah satu pihak merasa tidak dirugikan dalam pelaksanaan dilapangan. Namun sebelum itu mari kita lihat apa yang sesungguhnya kunci sukses bagi TKI dalam bekerja.

1. Tingkat Pendidikan. Pekerja adalah merupakan sosok atau insan yang selalu dirugikan bila terjadi perbedaan kepentingan antara pemerintah dan pengusaha. Kurangnya atase ketenagakerjaan di luar negeri, tidak maksimalnya perlindungan tenaga kerja Indonesia (TKI) sebagai akibat dari pengiriman TKI dengan tingkat pendidikan yang rendah (tamat SMP dan SMA). Sehingga para TKI sering menjadi korban dari kepentingan perusahaan atau majikan diluar negeri.

Hasil pengolahan data yang diperoleh tentang pengaruh pendapatan/upah terhadap pendidikan bagi TKI asal Sumatera Barat dengan jumlah sampel sebanyak 120, serta analisis yang dilakukan menggunakan Crosstab (Tabel Silang) dan uji Chi Square (kuadrat Chi) dengan bantuan program SPSS versi 15,0 for windows, dapat dilihat pada Tabel 1.

Di dalam Tabel 1 dapat dilihat bahwa TKI asal Sumatera Barat lebih banyak memiliki tingkat pendidikan yang rendah (SLTA) dengan pendapatan yang diperoleh antara Rp12 juta/bulan. Jika dilihat perbedaan pendapatan antara tingkat pendidikan tamatan SLTA dengan yang lebih tinggi yaitu tamatan Diploma tidak terlalu berpengaruh terhadap pendapatan TKI di luar negeri. Hal ini 
disebabkan karena sektor pekerjaan yang dimasuki oleh TKI adalah sebagai operator, dimana sektor pekerjaan ini tidak terlalu membutuhkan tingkat pendidikan bagi TKI.

Tabel 1. Pengaruh Pendapatan di Luar Negeri Terhadap Pendidikan Responden Crosstab

\begin{tabular}{|c|c|c|c|c|}
\hline \multirow{2}{*}{$\begin{array}{l}\text { Pendapatan di } \\
\text { Luar Negeri }\end{array}$} & \multicolumn{3}{|c|}{ Pendidikan Responden } & \multirow{2}{*}{ Total } \\
\hline & SMP & SLTA & Diploma & \\
\hline \multirow[t]{2}{*}{$\mathrm{Rp}<1 \mathrm{jt}$} & 13 & 20 & 18 & 51 \\
\hline & $68,4 \%$ & $36,4 \%$ & $39,1 \%$ & $42,5 \%$ \\
\hline Rp 1 - 2 jt & $\begin{array}{c}4 \\
21,1 \%\end{array}$ & $\begin{array}{c}21 \\
38,2 \%\end{array}$ & $\begin{array}{c}16 \\
34,8 \%\end{array}$ & $\begin{array}{c}41 \\
34,2 \%\end{array}$ \\
\hline \multirow[t]{2}{*}{$\mathrm{Rp}>2 \mathrm{jt}$} & 2 & 14 & 12 & 28 \\
\hline & $10,5 \%$ & $25,5 \%$ & $26,1 \%$ & $23,3 \%$ \\
\hline Total & $\begin{array}{c}19 \\
100,0 \%\end{array}$ & $\begin{array}{c}55 \\
100,0 \%\end{array}$ & $\begin{array}{c}46 \\
100,0 \%\end{array}$ & $\begin{array}{c}120 \\
100,0 \%\end{array}$ \\
\hline
\end{tabular}

Sumber: Hasil pengolahan data primer

Oleh kerana itu, keadaan yang ditemui agak berbeda dengan penemuan-penemuan yang biasanya dijumpai dalam kasus migrasi, Mengutip hasil penelitian Connell (1976) dan Khan (1983), Nasution (2001) mengemukakan bahwa bahwa penduduk yang pergi meninggalkan daerah asal lazimnya adalah yang berpendidikan relatif tinggi, sementara yang tidak dapat membaca dan menulis lebih suka tinggal didaerah asal.

Kedepan, apabila TKI ingin memasuki sektor pekerjaan formal lainnya yang lebih membutuhkan kualitas pendidikan seperti dokter, perawat atau bekerja pada perusahaanperusahaan besar di luar negeri, maka calon TKI harus meningkatkan kualitas pendidikan, Peningkatan kualitas pendidikan juga harus didukung oleh semua pihak melalui peningkatan kualitas kurikulum, staf pengajar, sarana dan prasarana belajar yang sesuai dengan perkembangan teknologi dengan memperhatikan kebutuhan pengguna.

Memang menjadi TKI bukanlah hanya pertimbangan skill atau teknis keahlian semata, tetapi pemahaman dan wawasan terutama budaya masyarakat tempat dimana mereka bekerja merupakan hal yang tidak bisa diabaikan begitu saja, Karena kualitas tenaga kerja dan tingkat pendidikan selalu memiliki keterkaitan. Sinergisme demikian ini bagi tenaga kerja Indonesia khususnya yang bekerja di luar negeri masih kurang. Di pandang dari segi penempatan, TKI yang mempunyai latar pendidikan pas-pasan lebih banyak ditempat- kan pada sektor informal seperti menjadi pembantu rumah tangga, sopir, perkebunan dan lain sebagainya.

2. Tingkat Keterampilan. Kompetensi melukiskan karakteristik pengetahuan, keterampilan, perilaku dan pengalaman dari tenaga kerja untuk memasuki dunia kerja secara efektif. Sedangkan pengetahuan melukiskan apa yang ada dalam pikiran seseorang (tenaga kerja) dengan tingkat kesadaran dan pemahaman mengenai pekerjaan yang akan dimasuki. Keterampilan melukiskan kemampuan yang dapat diukur melalui praktek, pelatihan atau pengalaman calon tenaga kerja agar memiliki kompetensi dalam bekerja karena kompetensi sangat dibutuhkan dalam memasuki dunia kerja saat ini.

Dalam meningkatkan kualitas keterampilan tenaga kerja, pihak pemberi pelatihan keterampilan seperti diklat-diklat adalah pihak yang bertanggungjawab terhadap peningkatan kualitas keterampilan yang diberikan. Peningkatan kualitas keterampilan dapat dilakukan dengan cara meningkatkan kualitas tenaga pelatihan, kurikulum yang diberikan, serta mengevaluasi terhadap kebijakan-kebijakan yang telah dibuat agar adanya upaya perbaikan yang sesuai dengan perkembangan teknologi dan informasi saat ini serta tetap memperhatikan kebutuhan pengguna. Dengan demikian pelatihan keterampilan yang diberikan harus berkelanjutan dan terus menerus sampai pada calon tenaga kerja sehingga tenaga kerja benar-benar memiliki keterampilan yang cukup.

Perusahaan PJTKI selaku pihak yang memfasilitasi pengiriman dan penempatan TKI di luar negeri harus memberikan keterampilan dan pembekalan akhir pemberangkatan (PAP) terhadap TKI. Program ini diwajibkan oleh pemerintah kepada calon tenaga kerja yang dikirim agar mereka mengetahui jenis pekerjaan yang akan dilakukan, peraturan yang berlaku serta kemampuan yang dimiliki untuk meningkatkan produktivitas kerja. Dalam menjalankan program ini harus melibatkan wakil-wakil semua instansi yang terlibat seperti pihak penyelenggara pelatihan keterampilan/diklat-diklat. 
Tabel 2. Pengaruh Keterampilan Terhadap Pendapatan Responden di Luar Negeri Crosstab

\begin{tabular}{lccc}
\hline $\begin{array}{c}\text { Pendapatan di Luar } \\
\text { Negeri }\end{array}$ & \multicolumn{2}{c}{$\begin{array}{c}\text { Keterampilan } \\
\text { Responden }\end{array}$} & Total \\
Ada & Tidak ada & \\
\hline Rp <1 jt & 17 & 34 & 51 \\
& $31,5 \%$ & $51,5 \%$ & $42,5 \%$ \\
Rp 1 - 2 jt & 22 & 19 & 41 \\
& $40,7 \%$ & $28,8 \%$ & $34,2 \%$ \\
Rp $>$ 2 jt/bln & 15 & 13 & 28 \\
& $27,8 \%$ & $19,7 \%$ & $23,3 \%$ \\
Total & 54 & 66 & 120 \\
& $100,0 \%$ & $100,0 \%$ & $100,0 \%$ \\
\hline
\end{tabular}

Sumber: Hasil pengolahan data primer

Dalam Tabel 2 terlihat bahwa TKI asal Sumatera Barat rata-rata tidak memiliki keahlian dan keterampilan dengan pendapatan antara Rp1-2 juta/bulan. Kalaupun ada TKI yang memiliki keterampilan (komputer, menjahit, dan mesin) jumlah sangat sedikit, Hal ini disebabkan karena para TKI setelah tamat SLTA mereka langsung ingin bekerja keluar negeri tanpa harus terlebih dahulu mengikuti pelatihan keterampilan atau meningkatkan kemampuan mereka sebagai bekal untuk meningkatkan hasil kerja. Di samping itu kondisi yang dilihat serta informasi yang diperoleh bahwa teman-teman mereka yang bekerja ke luar negeri hanya tamatan SLTA, sedangkan permasalahan yang dialami TKI di luar negeri lebih mengalahkan keinginan mereka untuk tetap mencari peluang kerja di luar negeri dibandingkan harus menciptakan lapangan kerja didalam negeri.

Untuk meningkatkan kemampuan keterampilan TKI agar dapat mengurangi permasalahan diluar negeri dapat dilakukan pada tingkat lembaga-lembaga atau diklat-diklat dengan cara meningkatkan kualitas tenaga pelatih, kesesuaian kurikulum dengan kebutuhan pasar, kelengkapan sarana dan prasarana pelatihan yang lebih mengacu pada kebutuhan pengguna di luar negeri.

Namun demikian, yang perlu disadari adalah apabila ingin bekerja diluar negeri baik disektor formal maupun informal pendidikan dan pelatihan kerja adalah salah satu persyaratan yang harus dipenuhi calon TKI agar dapat membekali, meningkatkan, dan mengembangkan kompetensi kerja untuk meningkatkan kemampuan dan produktivitas calon TKI sehingga benar-benar melaksanakan tugas dan kewajiban secara baik sehingga hak-haknya diperoleh secara layak.

\section{Kemampuan Mental (Keterampilan Non Skill TKI)}

Selain meningkatkan kualitas pendidikan dan keterampilan calon TKI, peningkatan kemampuan non skill TKI juga tidak kalah pentingnya, Karena pada umumnya mereka yang bekerja keluar negeri berasal dari kampung-kampung, di mana mereka sama sekali buta tentang aturan tenaga kerja dan bahkan untuk pergi ke kota (Padang) dengan seorang diri tanpa ditemani oleh keluarga belum pernah meraka lakukan apalagi pergi untuk bekerja keluar negeri. Tujuan pemberian keterampilan non skill ini adalah agar calon tenaga kerja memiliki mental yang kuat serta mengetahui gambaran bekerja keluar negeri itu seperti apa dan apa yang harus dipersiapkan. Selain itu pengetahuan di bandara, asuransi, perbankan dan pembekalan tentang agama harus dilakukan agar para calon TKI dapat mengetahui segala sesuatu yang berkaitan dengan hak dan kewajiban tenaga kerja.

4. Keunggulan TKI Asal Sumatera Barat. Tenaga Kerja Indonesia (TKI) asal Sumatera Barat menjadi incaran perusahaan-perusahaan diluar negeri karena TKI asal Sumatera Barat punya kelebihan tersendiri terutama dalam kedisiplinan dan mental kerja yang kuat. Di samping itu pemerintah daerah tidak memberikan izin untuk bekerja keluar negeri sebagai Pembantu Rumah Tangga (PRT). Alasannya sebagai antisipasi terjadinya permasalahan yang begitu kompleks di luar negeri serta menjaga imej bahwa orang Sumatra Barat di luar negeri tidak ada yang jadi pembantu. Di samping itu juga pemerintah daerah berupaya meningkatkan kualitas TKI dengan melakukan program pemagang di perusahaan-perusahaan di luar negeri, Program ini merupakan peningkatan kualitas keterampilan dibidang kontruksi dan praktek langsung terhadap dunia kerja di perusahan di Malaysia. Setelah selesai melakukan pemagangan peserta magang diberikan sertifikat atas keahlian yang dimiliki serta diakui oleh negara-negara lain. Di samping itu pemerintah daerah juga mengusahakan melakukan pemagangan di bidang lain seperti 
elektronik, perawat, dan lainnya, yang juga berharap diberikan sertifikat yang juga diakui di luar negeri. Ini merupakan langkah yang baik untuk meningkatkan tenaga kerja yang terampil untuk bekerja di luar negeri sehingga perlu dicontoh oleh daerah lain, (Wawancara dengan pihak Disnakertrans (10/3/2009 dan pimpinan PJTKI PT, Mitra Muda Raksa Mandiri, 23/4/2009).

\section{Analisis Ekonomi}

1. Pengaruh Pendapatan/Upah Terhadap Tingkat Pendidikan TKI. Berdasarkan hasil analisis dengan uji Chi Square memperlihatkan bahwa pengaruh pendapatan terhadap pendidikan TKI adalah Chi Square $_{\text {hitung }}$ adalah 4,817 dengan tingkat signifikan (asymp Sig) 0,090, derajat bebas $(d f)$ adalah 2 , sedangkan Chi Square $_{\text {tabel }}$ adalah 5,991. Maka Chi Square hitung $(4,817)>$ Chi-Square tabel $(5,991)$ pada probabilitas (asymp,sig) 0,05 maka Ho ditolak, yang berarti bahwa pendapatan berpengaruh terhadap tingkat pendidikan TKI yang bekerja di luar negeri. Artinya jika tingkat pendidikan yang ditamatkan oleh calon TKI yaitu pada tingkat SLTA maka pendapatan yang diterima lebih rendah dari tingkat pendidikan dengan tamatan perguruan tinggi dengan kata lain semakin tinggi tingkat pendidikan semakin besar pendapatan yang diterima.

Sebetulnya, sudah biasa bahwa TKI yang bekerja keluar negeri untuk meningkatkan kesejahteraan diri individu dan keluarganya karena dengan bekerja keluar negeri upah yang ditawarkan cukup tinggi. Berdasarkan data pada BNP2TKI sampai dengan akhir tahun 2008 jumlah TKI yang bekerja di luar negeri mencapai angka enam juta orang dengan sebagian besar bekerja di sektor informal dan uang yang dikirim (remittance) mencapai seratus tiga puluh ribu triliyun rupiah. Jumlah dana yang tidak sedikit ini menjadi sumber devisa bagi negara yang sudah pasti dapat memberikan kontribusi bagi perekonomian bangsa secara umum.

Selain itu, pengiriman TKI keluar negeri dapat mengurangi tingkat kemiskinan dan pengangguran di dalam negeri, juga telah membantu pengentasan kemiskinan bagi keluarga TKI di daerah asal melalui pengiriman uang dari TKI.

2. Pengaruh Pendapatan/Upah Terhadap Tingkat Keterampilan TKI. Selanjutnya, dilihat dari uji Chi Square antara pengaruh pendapatan terhadap keahlian keterampilan yang dimiliki oleh TKI memperlihatkan bahwa Chi Squarehitung adalah 4,878 dengan derajat bebas (df) adalah 2 dengan asymp,sig 0,087, sedangkan Chi Square tabel 5,991, Maka Chi Square hitung $(4,878)<^{\text {< }}$ dari Chi Square tabel $(5,991)$ maka Ho diterima, Asumsinya adalah tidak ada pengaruh pendapatan terhadap keterampilan yang dimiliki oleh TKI. Artinya bahwa pendapatan TKI asal Sumatera Barat di luar negeri tidak ditentukan oleh keahlian dan keterampilan yang dimiliki oleh TKI, karena TKI di luar negeri bekerja sebagai operator, di mana sektor ini tidak terlalu membutuhkan tingkat pendidikan dan keterampilan TKI.

Pemahaman lebih lanjut dari analisis yang dilakukan menyatakan antara lain: Pertama; sektor pekerjaan yang dimasuki TKI tidak terlalu membutuhkan keahlian atau keterampilan, sehingga keterampilan yang dimiliki oleh TKI tidak bisa diaplikasikan di tempat kerja dan tidak terlalu berpengaruh terhadap produktivitas yang dihasilkan, dan upah yang diterima juga sama dengan tenaga kerja yang memiliki keterampilan. Kedua, keahlian dan keterampilan yang dimiliki oleh TKI tidak diakui di luar negeri, karena tidak adanya standarisasi keterampilan yang diberikan kepada TKI oleh lembaga-lembaga tempat pelatihan didalam negeri. Pemberian pelatihan keterampilan kepada calon TKI tidak dilakukan secara terus menerus, berjenjang, berkelanjutan, dan tidak adanya kesesuaian kurikulum dengan kebutuhan pasar serta fakor lainnya. Seperti pelatihan manajemen yang diberikan tapi tenaga kerja yang sudah mengikuti pelatihan tidak ahli di bidang manajemen, atau sarjana pertanian tetapi tidak bisa bercocok tanam dan sarjana hukum tidak memahami bidang hukum.

Untuk ke depan, pelatihan kerja atau peningkatan kualitas TKI baik pendidikan dan keterampilan sebagai salah satu persyaratan calon TKI untuk dapat bekerja ke luar negeri agar dapat memiliki kedudukan strategis yang dimaksudkan untuk membekali, meningkat- 
kan, dan mengembangkan kompetensi kerja guna meningkatkan kemampuan, produktivitas calon TKI, sehingga calon TKI benar-benar dapat mlaksanakan tugas dan kewajibannya secara baik sehingga hak-haknya dapat diperoleh secara layak dan memiliki kesetaraan upah dengan tenaga kerja dari negara lain sekaligus meningkatkan martabat bangsa di mata Internasional.

\section{Dampak Peningkatan Kualitas Pendidikan} dan Keterampilan TKI. Dampak dari peningkatan kualitas pendidikan dan keterampilan yang selenggarakan sebaiknya dapat memberikan manfaat dalam jangka pendek dan jangka panjang bagi tenaga kerja maupun pemerintah. Hal ini dilakukan untuk mengantisipasi perkembangan teknologi yang mengalami perubahan begitu cepat dari waktu kewaktu, sehingga mau atau tidak kita harus mengikutinya agar tidak tertinggal, Dampak dari peningkatan kualitas pendidikan dan keterampilan bagi TKI antara lain:

4. Peningkatan Keahlian Kerja. Peningkatan keahlian kerja, sebenarnya tidak hanya keinginan perusahaan pengguna/user saja tetapi bagi tenaga kerja pun harus memiliki motivasi untuk meningkatkan kualitas (keahliannya) dalam bekerja serta produktivitas yang dihasilkan. Hal ini diharapkan agar dapat memperoleh kompensasi yang seimbang dengan pengorbanan dalam menyelesaikan pekerjaan, Peningkatan keahlian dalam bekerja bukan hanya semata-mata pada peningkatan pendidikan dan keterampilan saja. Kebiasaan untuk melakukan pekerjaan secara rutin setiap waktu dalam pekerjaan sejenis itu juga merupakan sarana juga untuk meningkatkan keahlian bagi tenaga kerja. Namun demikian, salah satu cara meningkatkan keahlian kerja dengan alokasi waktu yang cukup adalah melalui penyelenggaraan pendidikan dan pelatihan keterampilan,

5. Pengurangan Perpindahan Tenaga Kerja. Adapun penyebab umum terjadinya perpindahan tenaga kerja adalah karena kemampuan kerja yang tidak cocok dengan pekerjaan, upah yang rendah serta lingkungan kerja yang kurang mendukung. Namun tenaga kerja sebenarnya harus menyadari bahwa produktivitas yang dihasilkan sangat mempengaruhi upah yang diterima. Kalau produktivitas yang dihasilkan setiap tahunnya meningkat tetapi upah yang diperoleh tetap rendah, maka wajar tenaga kerja pindah ketempat yang lain. Di samping itu pihak terkait dalam hal ini pemerintah dan PJTKI selaku pihak yang memfasilitasi TKI keluar negeri harus memperhatikan keahlian dan keterampilan yang dimiliki TKI sebelum mereka diberangkatkan keluar negeri agar tidak dipandang sebelah mata oleh negara pengguna dalam memperkejakan mereka.

\section{Pengurangan Timbulnya Kecelakaan Kerja}

Timbulnya kecelakaan kerja biasanya sebagai akibat atas kelalaian dari tenaga kerja atau pihak perusahaan. Untuk mengatasi hal tersebut perlunya meningkatkan keahlian bagi tenaga kerja sehingga kesalahan yang diakibatkan oleh tenaga kerja bisa diminimalisir, seperti kerusakan produk yang dihasilkan, kerusakan mesin yang diakibatkan kurang cermatnya serta pengetahuan dalam bidang tersebut. Solusi dalam pengurangan kecelakaan kerja atau kesalahan kerja bagi TKI diluar negeri adalah dengan penyelengaraan pendidikan dan pelatihan keterampilan. Sehingga tenaga kerja benar-benar ahli di bidang pendidikan dan keterampilan yang diberikan dan sesuai dengan kebutuhan pasar.

7. Peningkatan Produktivitas Kerja. Tujuan perusahaan adalah untuk memperoleh profit (keuntungan) yang tinggi dalam setiap prosesnya sesuai dengan yang diharapkan. Banyak faktor yang dapat menunjang pencapaiannya antara lain kondisi kerja, semangat kerja dan produktivitas kerja. Sehingga kondisi kerja yang baik, semangat kerja yang tinggi dan produktivitas yang meningkat ditentukan oleh tingkat pendidikan dan keahlian serta keterampilan dari tenaga kerja itu sendiri. Tanpa didukung dengan pendidikan dan keterampilan yang cukup maka mustahil semua itu bisa diwujudkan.

8. Peningkatan Rasa Tanggungjawab. Memiliki rasa tanggungjawab yang tinggi terhadap pekerjaan yang dilakukan sangatlah dibutuhkan, dengan adanya rasa tanggungjawab maka adanya keinginan untuk menyelesaikan pekerjaan sesuai dengan waktu yang ditetapkan agar 
perusahaan dapat meningkatkan produktivitas, Peningkatan rasa tanggungjawab dapat diperoleh melalui peningkatan kualitas pendidikan dan keterampilan dari tenaga kerja serta memiliki mentalitas yang kuat.

Sekarang, ratusan ribu dan bahkan jutaan putra-putri Indonesia bekerja di luar negeri, Kondisi demikian akan terus mengulang sejarah pahit untuk bangsa Indonesia. Artinya kedepan, TKI akan terus mendapatkan perlakuan tidak baik dari sang majikan, atau orangorang lain di negara bersangkutan, Karena mereka (mungkin) memandang lurah tak berbatu terhadap warga negara Indonesia yang bekerja mencari nafkah di negara asing, Maka sudah saatnya pemerintah bersama PJTKI lebih selektif untuk mengirim TKI ke luar negeri. Setidaknya, harus ada hitam di atas putih yang bisa dipegang untuk kelangsungan hidup putra-putri kita di luar negeri. Sebaliknya, terhadap seluruh pencari kerja di negeri ini jangan mudah tergiur dengan besarnya gaji atau pendapatan lain-lain di luar negeri. Apalah artinya pendapatan besar kalau lahir bathin teraniaya, apalah gunanya gaji besar kalau mempertaruhkan nyawa. Namun jika ingin bekerja ke luar negeri maupun bekerja di dalam negeri perlunya meningkatkan kualitas pendidikan dan keterampilan sebagai antisipasi dan strategi untuk meningkatkan kesejahteraan ekonomi individu, keluarga dan bangsa Indonesia.

\section{Simpulan}

Pengiriman tenaga kerja keluar negeri memberikan dampak positif dalam menekan angka pengangguran didalam negeri. Agar tenaga kerja di luar negeri dapat bersaing dengan tenaga kerja dari negara lain maka harus memperhatikan kualitas pendidikan dan keterampilan yang dimiliki calon TKI serta perlunya kerjasama dengan duduk satu meja antara pemerintah dan perusahaan PJTKI untuk menyelesaikan permasalahan tenaga kerja diluar negeri. Implikasi dari kebijakan pengiriman TKI yang memiliki kualitas keluar negari bagi pemerintah daerah dapat mengurangi permasalahan ketenagakerjaan, dan meningkatkan pembangunan ekonomi daerah melalui remittance yang diterima dari tenaga kerja. Sedangkan bagi TKI, memperoleh upah yang lebih tinggi dan dibayar sama dengan tenaga kerja dari negara lain sehingga mampu meningkatkan ekonomi individu dan keluarga di daerah asal.

\section{Daftar Pustaka}

Bachtiar, Nasri. 2004. Blue Print Kebijakan Ekspor Jasa TKI ke Luar Negeri, Makalah Dalam Lokakarya Ketenagakerjaan yang disampikan di Kantor BAPPEDA Tk I, propinsi Sumatera Barat, 14/4/2004,

Darwis. 2004. Peluang Tenaga Kerja di Luar Negeri (Kabupaten Tulung Agung Propinsi Jawa Timur), Jurnal Ekonomi Lembaga Demografi FE-UI, Jakarta.

Elfindri \& Rimilton Riduan. 2008. Tahapan Pembentukan Kelompok dan Pendamping: Sebuah Rekonstruksi, Jurnal Ipteks Terapan Vol,2 No,2, Koperatis Wilayah X Sumbar, Riau, Jambi \& Kepri.

Febriani. 2008. Karakteristik Calon TKI Asal Sumatera Barat yang di Salurkan oleh PJTKI, Tesis, Padang: Program Pasca Sarjana Universitas Andalas.

Latief, Abdul. 1995. Membangun Sumber Daya Manusia yang Mandiri dan Profesional, Jakarta: Departemen Tenaga Kerja Republik Indonesia.

Nasution. 1997. Bangsaku di Tanah Seberang: Suatu Tinjauan awal Tetang Kesan Migrasi Pekerja Indonesia ke Malaysia Terhadap Pribadi Migran, Kertas Kerja Seminar Kerjasama Universitas Sumatera Utara dengan Universitas Malaya, Januari.

Nasution, Arif. 2001. Orang Indonesia di Malaysia Menjual Kemiskinan Membangun Identitas, Yogyakarta: Pustaka Pelajar.

Revenstein, E,G. 1998. The Laws of Migration, Journal of the Statistical society 48; 167-219,

Sugiyono Wibowo, 2004. Staistik untuk Penelitian dan Aplikasinya dengan 
dengan SPSS ver.10,0 for Windows, Wisnu Adi, Yuwono. 2007. Kajian Hukum Bandung: Alfabeta.

Waridin. 2002. Beberapa Faktor yang Mempengaruhi Migrasi TKI ke Luar Negeri, Jurnal Ekonomi Pembangunan (JEP), Vol,3 No,2 Desember 2002. terhadap Perlindungan Tenaga Kerja Indonesia ditinjau dari undang-undang no, 39 tahun 2004 tentang penempatan dan perlindungan tenaga kerja Indonesia di luar negeri, Thesis S2 Pasca Sarjana Fakultas Hukum Universitas Indonesia. 